probably influenced by temperature, pressure, and nature of the base neutralised. Ostwald's researches show that the affinity exerted between an acid and a base may be regarded as the product of the specific affinity-constants of the acid and of the base; i.e., as made up of two parts, one of which is dependent on the acid and the other on the base.

The connection between chemical structure and affinity is touched upon by Ostwald. His numbers show that while the relative affinity of acetic acid is represented by about $I \cdot 3$ (nitric acid $=100$ ), that of monochloracetic acid is represented by 7 , that of dichloracetic acid by 33 , and that of trichloracetic acid by 80 . Similarly, the entrance of oxygen into the molecule of an acid increases the affinity, while the addition of $\mathrm{CH}_{2}$ decreases the affinity. ${ }^{x}$

The importance of the results, a very short sketch of which I have endeavoured to give, cannot be overlooked. We seem approaching the time when exact knowledge will be obtained of that mysterious force, chemical affinity; but before this exact knowledge is attained, much work remains to be done. Not the least of the benefits bestowed upon their fellow chemists by the three naturalists whose papers I have mentioned, is that they have directed their attention to a branch of chemical science which, although it presents great difficulties, yet promises results of the most paramount importance to science.

Cambridge, August

M. M. PATtison Muin

\section{NOTES FROM ICELAND}

$\mathrm{D}^{\mathrm{u}}$ URING the last three weels the writer has travelled over between four and five hundred miles of country in Iceland, in the course of which various facts have presented themselves which may interest some of the readers of this journal. These "Notes" are necessarily desultory, because the main facts connected with the natural phenomena of the country are so well known that the most we can do is to supplement some of them.

Submarine Eruption off Cape Reykjanes.-The only eruption recorded in Iceland during the present year took place off Cape Reykjanes on May 30, near the Geirfuglasker island, thirty-two miles from land. It is described by a farmer named Guômundsson, living near Kirkjuvogr, and his account of it is published in the Heilorigdistindi for June last. Smoke appeared from the sea on May 3o, and on June $x$ it was carried inland by a west wind. For thirteen or fourteen days it was difficult to navigate the sea about Reykjanes on account of the smoke, and just before it cleared off, ashes fell on the coast lands. An appearance as of fire was also seen out at sea. This is positively all the information we possess concerning this eruption. It is sufficiently meagre, but the district about Cape Reykjanes is very thinly populated. The road, or track, is carried over a lava-stream, and is one of the worst in Iceland; the houses are few and far between, and the keeper of the lighthouse told us we were the only visitor he had seen this year. It is probable that volcanic phenomena often pass unnoticed in a country which is so thinly peopled, that with an area one-sixth larger than that of Ireland, the population $(72,000)$ is less than that of Norwich. Submarine eruptions have more than once previously taken place in this district; small volcanic islands have been raised above the level of the sea, and have sunk again, leaving dangerous reefs. At Cape Reykjanes (hence the name) there are numerous hot springs which deposit silica, and which are therefore of the same nature as the geysirs. The springs rise through beds of highly decomposed tuff ; large quantities of steam are emitted, and the soil in the vicinity is so soft that it is necessary to carefully choose one's footing. Pools of

I The results of Ostwald, and also those of Guldberg and Waage, are corroborative of those obtained by Dr. C. R. A. Wright in a paper published in the Phit. Atar., December, I874. boiling blue mud (like the maccalube near Girgenti) are also found in the vicinity.

Craters of the Eruption of Hekla of February, 1878.Last autumn we gave an account in this journal (vol. xviii. p. 596) of a visit to the scene of the new eruption, which took place about four miles from the principal craters of Hekla at the end of the preceding February. The observations of Herr Nielsens, a merchant of Eyrarbakki, and of Prof. Tomas Hallgrimson, were also recorded. The former has just communicated to the writer the result of certain measurements of the principal of the new craters, which he made a few months ago. Three of the craters in the centre of the group were measured. The form of the first is that of a funnel, roo Danish feet ${ }^{1}$ in diameter. A good deal of steam issued from the bottom of the crater, and prevented the depth from being accurately determined, but it appears to be about 150 feet. The second crater is of horseshoe form, the straight wall joining the curve of which, is perfectly vertical. The diameter increases as it descends, being at the top about 30 feet, and at the bottom 50 ; while the depth is also 50 feet. The third crater is of the shape of a parallelogram, 40 feet long by 30 broad, and 40 feet deep. The walls are perpendicular. No lava issued from the second and third of these craters, but quantities of ash and pumice. The greatest quantity of lava flowed from the most southerly crater nearest to the summit of Hekla. The approach to this is very difficult on account of the extreme jaggedness of the lava. The whole field of new lava appears to be covered with an innumerable quantity of small craters, but a closer examination proves that they have been produced by the molten lava beneath forcing out portions of the upper soliclified crust, at places where snow or water caused the generation of large quantities of steam. Most of the real craters are split in twain, and the sides are lined with incrustations of common salt.

A few weeks ago Miss Thora Pjetùrssen, of Reylkjavik, ascended Hekla, and reports the appearance of steam from one of the main craters; last year when we ascended the mountain no trace of steam appeared from any one of the three main craters, the most recent of which was formed in 1845 . Hekla only enters into eruption at long intervals of time.

Slight shocks of earthquake are common in the southeast districts, in Guldbringu Sysla and Rangarvalla Sysla.

Climate.-The presence of jokulls covered with perpetual snow; of the Gulf Stream, and of an arctic current, tend to make the climate of Iceland very variable and subject to sudden changes. On August 2o, when we left Kalmanstunga, in the centre of the island, the sun was as hot as during an English mid-August day; later in the day as we passed the Geitlands jokull a piercing icy wind bore down upon us with great force, and again towards evening when we entered the northern end of the Thingvellir valley it was warm and summer-like. During the course of that day we experienced a difference of more than $100^{\circ} \mathrm{F}$. Again on August 30, at Eyrarbakki, on the south coast, $N$. lat. $63^{\circ} 65^{\prime}$, the thermometer at 6 A.M. stood at $-\mathrm{r}^{\circ} \mathrm{R} .=29^{\circ} 75 \mathrm{~F}$, and a crust of ice had formed on all exposed water. At ro A.M. a bright hot August sun was shining and the air was still. At 3 P.M. rain and violent wind occurred, and towards evening it again cleared up. Frequently the wind drops suddenly, and a complete change of weather may take place in the course of a few hours. The summer has been unusually dry and warm, but on August $3 \bar{I}$ the weather began to break up. On that day we travelled from Eyrarbakki to Reykjavik by way of Reykir (in Olfusahreppr), and we shall never forget the difficulties of crossing the Helliskard, a low spur of the mountain Hengill. The whole tract is either the living palagonite rock, or detached fragments heaped together in confusion. Hence it is only possible to proceed at a slow space. A violent wind

$\therefore$ One Danish foot $=x^{\prime} \times 25$ English foot. 
swept over the face of the mountain, driving the rain in almost horizontal sheets along the surface. From time to time mists floated over the mountain, and it was bitterly cold.

Iceland a Meteorological Station.--If Iceland were connected with the Faerroe Islands, and with the north of Scotland by telegraph, there can be no doubt that it would form a valuable meteorological station, although from the various disturbing influences the effect of which would be comparatively local, such as the jokulls and the various local currents, such a station would be less valuable than would be afforded by a vessel moored 600 or 800 miles out in the Atlantic between Ireland and Newfoundland, and in telegraphic communication with the central office in London.

Drift Wood of Iceland.-Great quantities of drift wood are thrown upon the southern coast of Iceland. It is said to be chiefly fir, and it is asserted by some to come from Siberia by an arctic current, and by others from America by the Gulf Stream. We noticed that the coast between Grindavik Staor and Cape Reykjanes was far more thickly strewn with drift wood than the coast more to the east in the neighbourhood of Eyrarbakki. As the Gulf Stream impinges on the south-western peninsula, it would seem that it must therefore be the chief source of the drift wood. The trees that we saw were torn up by the roots, and they were completely blanched, and in many cases riddled with holes by some species of borer. A portion of the skeleton of a large whale was visible on the shore near Grindavik.

Improvements in Iceland.-During the year which has elapsed since we last visited Iceland, several very marked improvements have been set on foot. In no respect is this more conspictous than in the case of the roads. A few years ago a writer made the assertion "there are no roads in Iceland." At the present time road-making is making great progress, and many scores of miles of excellent roads exist. Of course we mean such roads as alone are possible, without great expenditure of money and labour, in a country which is one vast volcano. Driving roads are impossible, but excellent pony roads are being constructed, and will greatly facilitate despatch of business and intercommunication. The first bridge in Iceland is about to be commenced. It will cross the Olfusà, and materially help to establish a better communication between the east and the west. A second bridge is to be thrown across the Thjorsa. The first lighthouse in the island was erected a year ago, and the lightdues paid by ships at the port of Reykjavik have already almost paid for its construction. There is some talk of founding a school of farming at Moorrudalr in the northwest, and a law school in Reykjavik, where a divinity school and a medical school already exist. In Reykjavik new houses are being built; there is a proposition on foot to build an hotel, and a new house for the Althing, which now holds its biennial meetings in the Latin school. Hafnafjord and Eyrarbakki are flourishing little ports; Akureyri does a fair trade in shark liver oil, and in ponies; and the Krisuvik sulphur mines appear to be in good working order, and to yield a rich product.

Reykjavik, September 2

G. F. RODWELL

\section{ON HARMONIC RATIOS IN THE SPECTRA$$
\text { OF GASES }
$$

PROF. G. JOHNSTONE STONEY has given in the April number of the Phil. Mag. for I 87 I some remarkable ratios of the wave-lengths of three of the hydrogen lines. Prof. Soret and Mr. Lecoq de Boisbaudran have also given several similar ratios, and I have found at various times a great many. It is, however, impossible to decide, without a thorough discussion, how many of these harmonic ratios may be due to accident. All possible fractions in a given spectrum ought to be calculated, and we could then see, by the theory of probability, whether the coincidences with ratios of comparatively small numbers are more numerous than we ought to expect. I began this work about a year ago. The calculation and discussion of twenty thousand fractions will necessarily take some time. The following simple ratios, however, which I have found in the iron-spectrum, I believe to be worth recording. I may say that I have gone only through the seventh part of that spectrum as yet. The first column in the following table contains the corrected wavelengths of iron lines as given by Angström. If these numbers are multiplied by the fractions given in the second column, we obtain the calculated values of other iron lines. The observed values and difference are given in the fourth and fifth columns.

\begin{tabular}{|c|c|c|c|c|}
\hline$\lambda$ & Fraction. & Calculated. & Observed. & $\Delta$ \\
\hline $6302 * 49$ & $8: 10$ & $5041 \cdot 99$ & $504 \mathrm{I} \cdot 69$ & -0.30 \\
\hline $623 r \cdot 64$ & $5: 6$ & 5193.03 & $5193^{\circ} 25$ & +0.21 \\
\hline \multirow[t]{2}{*}{$6192 \div 43$} & $9:$ ro & 5573.19 & $5573 \cdot 37$ & +0.18 \\
\hline & $6: 7$ & 5307.80 & $5308 \cdot 10$ & +0.30 \\
\hline \multirow[t]{2}{*}{$6137 \cdot 53$} & $8: 9$ & $5455 \cdot 58$ & $5456 \cdot 36$ & $\div 0.72$ \\
\hline & $7: 8$ & $5370 \cdot 34$ & $5370 \cdot 65$ & +0.31 \\
\hline \multirow{2}{*}{$\begin{array}{l}6066 \cdot 39 \\
60093^{2}\end{array}$} & $7: 8$ & $5308 \cdot 09$ & $5308 \cdot 10$ & $+0^{\circ} \mathrm{OI}$ \\
\hline & $\begin{array}{l}8: 9 \\
2: 3\end{array}$ & $5341 \cdot 62$ & $5341 \cdot 87$ & +0.25 \\
\hline \multirow[t]{2}{*}{$6003^{\circ} 92$} & $7: 10$ & $42020^{\circ} 74$ & $4202 \cdot 75$ & +0.0I \\
\hline & $5: 6$ & 5003.27 & $5003 \cdot 52$ & +0.25 \\
\hline
\end{tabular}

The differences could of course be reduced to one-half by throwing part of them on the possible errors in the observation of the wave-lengths given in the first column. It is to be remarked that the intensities of the iron lines which figure in the above table are as a rule very strong. Thus all but three of the lines have an intensity of over six attached to them in Watts' Index.

The following table contains a set of iron lines, which can be arranged as harmonics of a fundamental vibration whose wave-length is $0^{\circ} 018694765$ of a millimetre.

The table is arranged according to the pattern of that given by Prof. Stoney for the hydrogen lines.

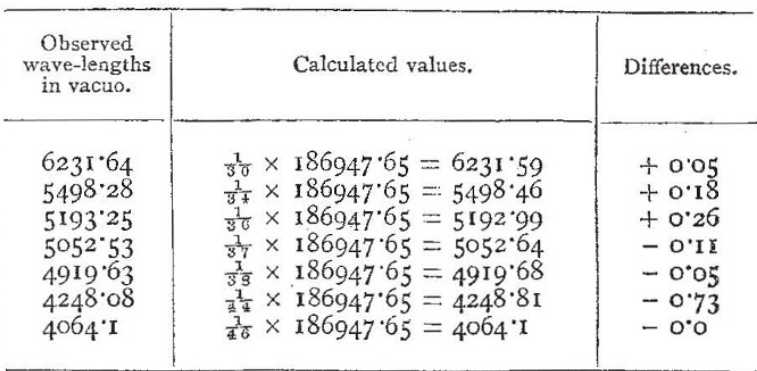

I have included the forty-fourth harmonic, because Thalén gives 4248.8 for the observed value of the wavelength, which reduces the difference to zero. I must, of course, complete the investigation before I can definitely say in how far all these coincidences may be due to accident. On the whole, as far as I have hitherto gone, the result does not seem to be decisive in favour of such a simple connection between the wave lengths of different lines. The true law of the distribution has not yet, I believe, been found, but harmonic ratios may take a secondary part. ARTHUR SCHUSTER

\section{OUR ASTRONOMICAL COLUMN}

PALISA's COMET. - The following elements of this comet have been calculated by $\mathrm{Mr}$. Hind from the first Pola observation on August $2 \mathrm{I}$, one at Leipsic on August 28, and M. Henry's observation at Paris on September I I:- 